\title{
Global patterns of macroinvertebrate production in marine benthic habitats*
}

\author{
Mathieu Cusson $^{1, * *}$, Edwin Bourget ${ }^{2}$ \\ ${ }^{1}$ Département de Biologie, Québec-Océan (GIROQ), Université Laval Québec, Québec G1K 7P4, Canada \\ ${ }^{2}$ Present address: Vice-rectorat à la recherche, Université de Sherbrooke, Sherbrooke, Québec J1K 2R1, Canada
}

\begin{abstract}
Using data published in 15 major marine ecology journals (from 1970 to 1999), we examined global patterns of marine benthic macroinvertebrate production and its distribution among feeding guilds and taxonomic groups and physical variables such as substratum type, water depth and temperature. Our database contains 547 production datasets, from 147 studies including 207 taxa, assessed by classical methods (cohort and size-based methods), from 170 sites ( $77^{\circ} 50^{\prime} \mathrm{S}$ to $69^{\circ} 35^{\prime} \mathrm{N}$; 0 to $930 \mathrm{~m}$ depth). In general, higher values of production to biomass (P/B) ratios were observed in the Northern Hemisphere than in the Southern Hemisphere. High values of P/B ratios were observed in mid-latitudinal zones while low values of $\mathrm{P} / \mathrm{B}$ ratios were observed in high $\left(80\right.$ to $\left.60^{\circ} \mathrm{S}\right)$ and low latitudinal zones $\left(40^{\circ} \mathrm{S}\right.$ to $\left.20^{\circ} \mathrm{N}\right)$. Highest production was observed on hard substrata, for filter feeders and for mollusc (e.g. bivalves) species. Highest P/B ratios were observed on algae (or high organic substrata), omnivores and predators, and arthropods (e.g. amphipods). Regression models explained a significant percentage of the amount of variance of benthic production $(92 \%)$ and P/B ratios (50 to $86 \%$ ). Production and $\mathrm{P} / \mathrm{B}$ ratios were negatively related to water depth and positively related to water temperature, but these abiotic variables did not greatly improve the predictability of production by biotic variables (e.g. life span, mean body mass). Biotic variables were more important than environmental variables in explaining observed variations in production and P/B ratios. For the latter, life span explained most ( 45 to $83 \%$ ) of the variation of the models.
\end{abstract}

KEY WORDS: Secondary production - P/B ratios · Invertebrates · Global scale - Empirical model of production $\cdot$ Benthos $\cdot$ Environmental factors

Resale or republication not permitted without written consent of the publisher

\footnotetext{
* Contribution to the program of Québec-Océan (Groupe interinstitutionnel de recherches océanographiques du Québec)

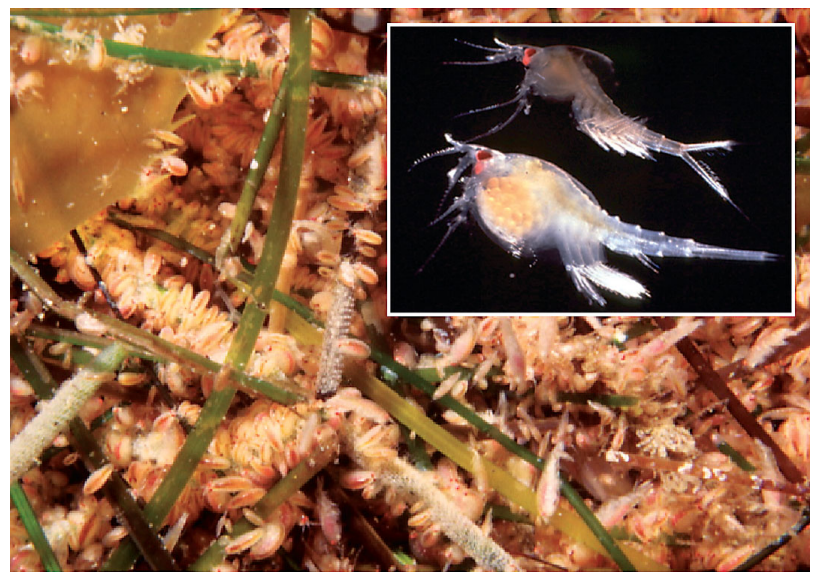

Patterns of benthic macroinvertebrate production were identified by meta-analysis of the literature. Production in the detrital mats from the Scripps Submarine Canyon (California) is among the highest reported from natural environments. Here, crustaceans such as Nebalia hessleri (inset) can reach densities up to $3.5 \times 10^{6}$ ind. $\mathrm{m}^{-2}$ and an annual production of $4.3 \mathrm{~kg}$ dry weight $\mathrm{m}^{-2} \mathrm{yr}^{-1}$.

Photos courtesy of E. W. Vetter and D. Stokes (Scripps Institution of Oceanography). Used by permission

\section{INTRODUCTION}

Secondary production, the estimate of incorporation of organic matter or energy per unit of time and area, integrates the influence of numerous biotic variables and environmental conditions affecting individual growth and population mortality. The global patterns of benthic production and production to biomass (P/B) ratios are known to be mainly functions of or affected by life history characteristics such as population biomass and density, body mass, recruitment, age, life span, taxonomy and trophic status (Waters 1977, 1979,

(C) Inter-Research $2005 \cdot$ www.int-res.com 
Rigler \& Downing 1984). Marine habitats offer a diversity of conditions such as soft and hard substrata, macrophytes, and a larger gradient of water depth and temperature than freshwater environments. Temperature and depth gradients are known to be important variables affecting metabolism and growth of invertebrates as well as the availability of food (Bayne \& Worrall 1980, Fréchette \& Bourget 1985, Brey \& Hain 1992) and food quality (Willows 1987, Vetter 1998), and hence production levels (Nakaoka 1992, Littorin \& Gilek 1999). Thus marine habitats vary in their quality, particularly in the availability of food (quality and quantity) they supply to benthic organisms. Trends of P/B ratio among environments (e.g. polar and nonpolar regions) have been investigated and they indicate the importance of both biotic (taxonomic origin) and abiotic factors (temperature and depth) (Brey \& Clarke 1993).

The best way to correctly assess the somatic production of benthic animals is to use methods based on time series measurement of population densities and body size or mass (e.g. cohort and size-based methods). This classical approach, however, requires expensive and time consuming sampling programs (Rigler \& Downing 1984). Empirical models have been developed to examine the link between macrobenthic production and biotic and environmental variables and to estimate production from environmental data without the requirement of intense sampling programs. Models have been conducted for freshwater (Banse \& Mosher 1980, Plante \& Downing 1989, Morin \& Bourrassa 1992, Benke 1993) and marine habitats (Robertson 1979, Edgar 1990, Tumbiolo \& Downing 1994, Cartes et al. 2002), or for both types of biota (Schwinghamer et al. 1986, Brey 1990b, 1999a, 2004). These studies explored the effect of biotic variables such as maximum body mass, life span, mean body mass, population biomass, motility and abiotic variables such as water depth and temperature on production and P/B ratios.

Large-scale patterns of marine benthos have been conducted for diversity (Rex et al. 1993, Flach \& de Bruin 1999, Attrill et al. 2001, Hillebrand 2004), richness (Culver \& Buzas 2000, Gray 2001, 2002, Macpherson 2002) and biomass (Brey \& Gerdes 1997, Brey 1999b, Ricciardi \& Bourget 1999), but much less attention has been given to their secondary production rates. In this paper we develop empirical models for marine benthic production using a large dataset. We extend the study of Tumbiolo \& Downing (1994) to a larger number of study sites (170 for our study vs. their study of 34 sites), a greater depth range (from 0 to $930 \mathrm{~m}$ vs. 0 to $300 \mathrm{~m}$ ), use production values from a higher number of taxa (207 taxa vs. 60 species), and use additional information in relation to depth, habitats and feeding groups. The present study examines the distribution of secondary production in different habitats of the world's oceans and extends empirical relations of marine secondary production to the global system. The specific objectives of this study were to: (1) describe general patterns of benthic secondary production in various marine habitats, and determine the relative importance of environmental variables (particularly the effect of the nature of substratum, such as sand, mud, rock, and organic substrata including macrophytes); (2) determine trends of production among taxonomic and functional guilds; (3) produce robust empirical equations to estimate production from a variety of taxa and marine habitats; and (4) examine the reliability of published marine empirical equations for estimating production.

\section{METHODS}

A complete literature review of marine benthic invertebrate production was conducted using 15 biological journals (Table 1 ) over a period of $30 \mathrm{yr}$, from 1970 to 1999 inclusive. All studies on macrobenthos (retained on a $0.5 \mathrm{~mm}$ screen size) from marine, estuarine and lagoon environments were considered (>2 practical salinity units, PSU; excluding salty and coastal lakes). The list of papers used for this study is in Appendix 1, available at: www.int-res.com/journals/ suppl/cusson_appendix.pdf.

We focused the analysis on those studies estimating the annual somatic production (including shell and

Table 1. Journals included in the meta-analysis (1970 to 1999)

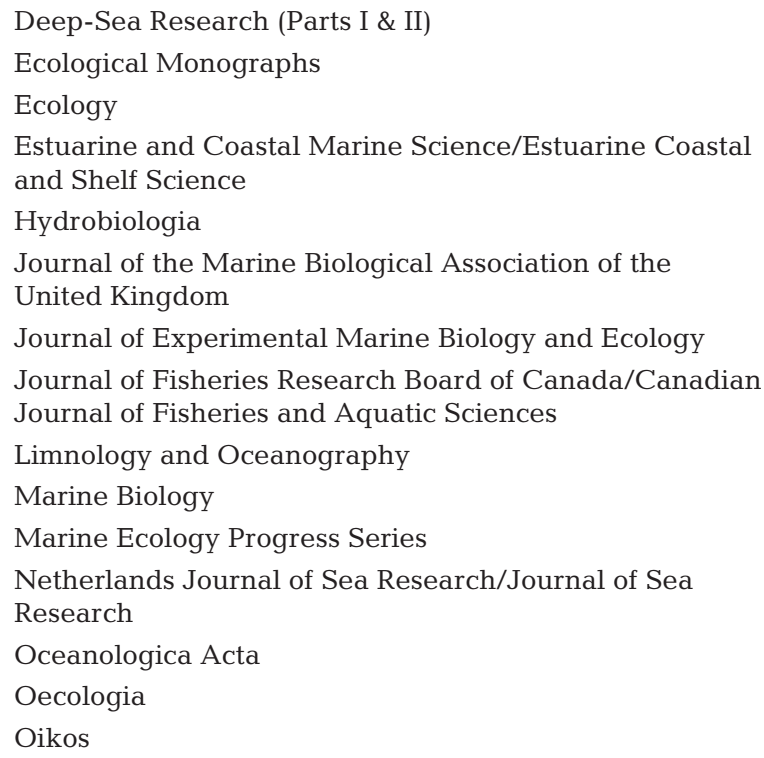


byssus for bivalves) of natural (unexploited) populations assessed with cohort-based (increment summation, removal summation, Allen curve and instantaneous growth rates) and size-based methods (size-frequency and mass-specific growth rates). Production studies from experimental plots, manipulated densities or in vivo growth studies, and those assessed by empirical regression models or by standard P/B ratios were excluded. We retained all information about methods used for production assessment and sampling design procedures. Most of these studies were of steady-state populations, but a few contained a small number of production values from non-steady-state populations. In a few cases where the papers contained sufficient data (e.g. growth and mortality functions, age- or size-specific growth rates or mortality curves, age- or size-specific densities) to estimate an annual production for the population, these were not retained to avoid rough assessments. Of the 203 papers assessing invertebrate macrobenthos annual production, 147 were included because they used classical assessment methods (cohort and size-based). The database contained 547 production datasets (56\% of which were infaunal) from 179 natural sites $\left(77^{\circ} 50^{\prime} \mathrm{S}\right.$ to $69^{\circ} 35^{\prime} \mathrm{N} ; 0$ to $\left.930 \mathrm{~m}\right)$. Intertidal datasets accounted for $44 \%$ (243) of the total database.

From each paper, we collected information about population and environmental parameters (Table 2). The life span was derived from the age of the oldest cohort in the population, with the assumption that the sampling had not been age-selective. Mean body mass was calculated by dividing the mean annual biomass by the mean annual density. Maximum body mass was derived from the maximum mass reached by the largest size class observed. Specific feeding guilds were noted when mentioned, completed or identified from general zoological references (e.g. Barnes 1987, Pechenik 1991). When available, the mean annual water temperature near the seabed (or the surface water temperature at some shallow sites), the depth of sampling site, and substratum types were collected.

Table 2. Ranges and median values for all continuous variables used

\begin{tabular}{|lccc|}
\hline Variable & Range (min.-max.) & Median & $\mathrm{N}$ \\
\hline Annual production $\left(\mathrm{kJ} \mathrm{m}^{-2} \mathrm{yr}^{-1}\right)$ & $0.0034-72950$ & 40.83 & 541 \\
Annual P/B ratio $\left(\mathrm{yr}^{-1}\right)$ & $0.004-36.7$ & 1.96 & 536 \\
Mean annual biomass $\left(\mathrm{kJ} \mathrm{m}^{-2}\right)$ & $0.005-93536$ & 19.72 & 524 \\
Mean body mass $\left(\mathrm{kJ} \mathrm{ind}^{-1}\right)$ & $0.00009-985.9$ & 0.071 & 443 \\
Life span $(\mathrm{yr})$ & $0.2-50$ & 2 & 414 \\
Water depth (m) & $0-930$ & 0.5 & 539 \\
Mean annual water temperature $\left({ }^{\circ} \mathrm{C}\right)$ & $-1.8-30$ & 12 & 547 \\
Mesh size $(\mathrm{mm})$ & $0.06-10$ & 0.5 & 467 \\
\hline
\end{tabular}

The latter variable was catalogued as follows: algae (including macrophytes and high organic enriched substratum), hard (rocky bed, boulder, cobble, wood substratum) sandy (dominant fraction) and muddy substrata.

All mass units were transformed into $\mathrm{kJ} \mathrm{m}^{-2}$ using conversion factors provided by the original source or by other literature sources (Ricciardi \& Bourget 1998, Brey 2004). Data expressed per meter of beach were transformed to $\mathrm{m}^{2}$ when beach width was available. When biomass was preserved in alcohol and/or formalin, a correction factor of 1.2 was applied to compensate the weight loss caused by the preservative as suggested by Brey (1986).

Data analysis. For each dominant taxonomic group (annelids, arthropods, echinoderms and molluscs) analysis of covariance (ANCOVA), with mean annual temperature as a covariate, was used to examine differences among substratum types and functional guilds (and crossed factors) on P/B ratios $\left(\mathrm{yr}^{-1}\right)$. Nonsignificant factors were removed from the models to increase the degree of freedom (df) of the error term. ANCOVAs were also used to examine differences among latitudinal and salinity classes on $\mathrm{P} / \mathrm{B}$ ratios (all taxa pooled). Eight latitudinal classes were used (each with a range of 20 degrees of latitude) to compare shallow (intertidal to $\leq 20 \mathrm{~m}$, to avoid interference with deeper sites and regroup sites likely to be influenced by wave action) P/B ratios among geographical regions, and 3 salinity classes were used $(<15,15$ to $<25$, and $\geq 25$ PSU) to compare $\mathrm{P} / \mathrm{B}$ ratios among regions with low salinity (e.g. estuaries). Despite the fact that production and $\mathrm{P} / \mathrm{B}$ ratios are linked to more than 1 parameter (biotic or abiotic) our database structure prevented the concurrent use of more than 1 or 2 covariates in this first step (for multivariate analyses, regressions were used: see below). Moreover, our dataset was not balanced among factors (substratum type, functional guilds, latitude and salinity classes), which prevented the analysis of more than 2 factors at the same time. For example, overall, $\mathrm{P} / \mathrm{B}$ ratios were negatively correlated with body mass (kJ ind. ${ }^{-1} ; \mathrm{p}<0.0001 ; \mathrm{R}^{2}=0.42$ ), and thus could be used as a potential covariable in ANCOVA. For all analyses (except for annelids) mean body mass could not be used as a covariate due to the lack of statistical independence between body mass and treatments (i.e. factors) and because the relationship (slope) between $\mathrm{P} / \mathrm{B}$ ratios and body mass was heterogeneous among factor categories (Underwood 1997).

Multiple regression analyses were used to link biotic and abiotic parameters to production and $\mathrm{P} / \mathrm{B}$ ratios. 


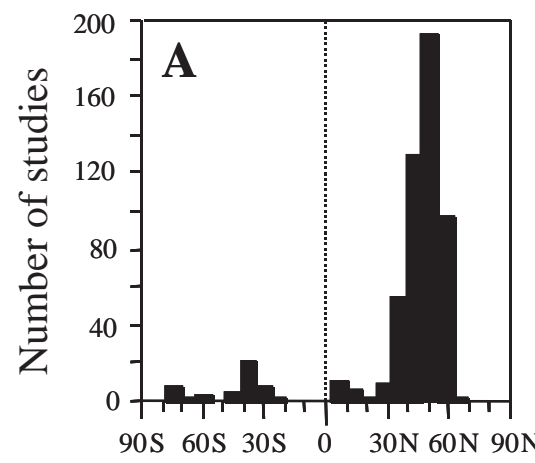

Latitude

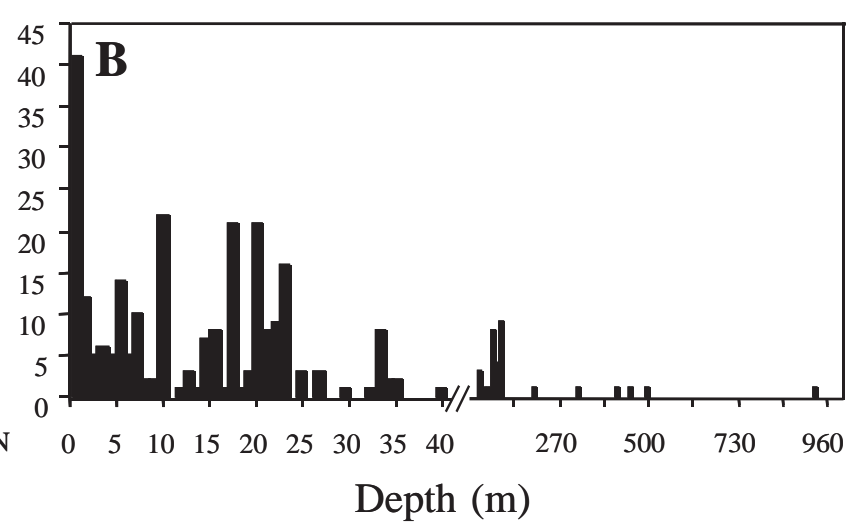

Fig. 1. Frequency distribution of production data studies used in our dataset $(\mathrm{n}=547)$ according to (A) latitude and (B) depth (intertidal data not shown)

Stepwise multiple regressions were used to examine the relationships between dependent variables (mean annual production and $\mathrm{P} / \mathrm{B}$ ratios) and biological variables (mean annual biomass, mean body mass, life span), environmental conditions (temperature, water depth of sampling site) and mesh size. Regressions were used with all the dataset (general models), or for dominant taxa (amphipods, bivalves, echinoderms, gastropods and polychaetes) or for given substratum or depth categories (specific models). Often available data were not sufficient to produce a regression model with all explanatory variables (e.g. mean body mass, life span, mean annual temperature, etc.), in which case the data included in each model were less than 547 and may vary among specific models. Regression models for decapods and isopods were not carried out due to insufficient data. Regression coefficients for a given independent variable were compared using their $95 \%$ confidence intervals ( $\pm 1.96 \mathrm{SE})$.

Robustness of the regression models was evaluated by the leave-one-out cross-validation method (Stone 1974). This test systematically excludes 1 data point at a time and predicts its value with the regression model adjusted with the remaining dataset. The coefficients of determination between observed and predicted values were computed to ascertain the significance of the new models. Published regression models were compared on the basis of their ability to predict our observed production data. Production was predicted from the models using independent variables from our dataset, and then correlated with the observed production from the same dataset. Mean residuals (observed production minus predicted production) $\pm \mathrm{SE}, \mathrm{R}^{2}$ and mean square error (MSE) were assessed and compared. In addition, the $\mathrm{R}^{2}$ of the published models, partly based on the same marine datasets, were compared among them on the basis of their ability to pre- dict our observed production data with a dependent correlation coefficient test (Williams $t$-test; Neill \& Dunn 1975, Steiger 1980).

The boxcox method was used to select the most appropriate transformation of dependent variables. Normality was verified using the Shapiro-Wilk's test (Zar 1999) and homoscedasticity was confirmed by graphical examination of the residuals (Scherrer 1984, Montgomery 1991). Production, P/B ratio, mean annual biomass, mean body mass and life span were $\log _{10}$ transformed to normalize the data. Protected Fisher LSD multiple comparison tests were carried out to determine differences among factors (Milliken \& Johnson 1984). All data were analysed using MIXED and REG procedures with SAS software (SAS Institute 1999). A significance threshold of 0.05 was adopted for all statistical tests.

\section{RESULTS}

Annual mean production, biomass and $\mathrm{P} / \mathrm{B}$ ratios of the 207 taxa included in the analysis ranged from 0.0034 to $72950 \mathrm{~kJ} \mathrm{~m}^{-2} \mathrm{yr}^{-1}, 0.0046$ to $93536 \mathrm{~kJ} \mathrm{~m}^{-2}$ and 0.0035 to $36.7 \mathrm{yr}^{-1}$, respectively. Four negative annual production values were reported, which were not included in the analysis due to the log transformation. The major taxonomic groups were bivalves $(36 \%)$, polychaetes $(20 \%)$, amphipods $(15 \%)$, gastropods $(7 \%)$ and echinoderms $(5 \%)$. Our database included data from various habitats worldwide, with a strong representation of northern latitude and shallow habitat studies (Fig. 1). Salinity ranged from 4 to 45 PSU (median $=26.5$ ). We observed no significant differences in production (ANOVA, $F=0.5, \mathrm{p}=0.6848$ ), biomass (ANOVA, $F=0.02, \mathrm{p}=0.9795$ ) or $\mathrm{P} / \mathrm{B}$ ratio (ANCOVA with mean annual temperature, $F=1.77$, $\mathrm{p}=0.1726$ ) among salinity classes (Table 3 ). 
Table 3. Summary of ANCOVAs with mean annual temperature as a covariate (and with mean body mass for annelid P/B ratios) showing the effect of (A) salinity classes, (B) latitudinal classes (intertidal to $20 \mathrm{~m}$ depth), and substratum type and feeding guilds for (C) molluscs, (D) annelids, (E) arthropods and $(\mathrm{F})$ echinoderms on mean $\mathrm{P} / \mathrm{B}$ ratios. $\mathrm{P} / \mathrm{B}$ ratios and mean

body mass were log transformed to normalize the data

\begin{tabular}{|c|c|c|c|}
\hline Source of variation & $\mathrm{df}$ & $F$-value & $\mathrm{p}$ \\
\hline \multicolumn{4}{|l|}{ (A) Salinity classes } \\
\hline Mean annual temperature & 1 & 14.82 & $<0.0001$ \\
\hline Salinity classes & 2 & 1.77 & 0.1726 \\
\hline Error & 286 & & \\
\hline \multicolumn{4}{|l|}{ (B) Latitudinal classes } \\
\hline Mean annual temperature & 1 & 9.30 & 0.0024 \\
\hline Latitudinal classes & 5 & 12.43 & $<0.0001$ \\
\hline Error & 400 & & \\
\hline \multicolumn{4}{|l|}{ (C) Molluscs } \\
\hline Mean annual temperature & 1 & 13.16 & 0.0004 \\
\hline Feeding guilds & 4 & 6.46 & $<0.0001$ \\
\hline Error & 219 & & \\
\hline \multicolumn{4}{|l|}{ (D) Annelids } \\
\hline Mean body mass & 1 & 10.94 & 0.0019 \\
\hline Mean annual temperature & 1 & 25.01 & $<0.0001$ \\
\hline Substratum type & 3 & 8.34 & $<0.0001$ \\
\hline Feeding guilds & 3 & 3.64 & 0.0153 \\
\hline Error & 100 & & \\
\hline \multicolumn{4}{|l|}{ (E) Arthropods } \\
\hline Mean annual temperature & 1 & 41.08 & $<0.0001$ \\
\hline Substratum type & 3 & 11.21 & $<0.0001$ \\
\hline Feeding guilds & 4 & 1.79 & 0.1350 \\
\hline Substratum type $\times$ Feeding guilds & 10 & 10.19 & $<0.0001$ \\
\hline Error & 126 & & \\
\hline \multicolumn{4}{|l|}{ (F) Echinoderms } \\
\hline Mean annual temperature & 1 & 4.40 & 0.0495 \\
\hline Substratum type & 2 & 17.38 & $<0.0001$ \\
\hline Feeding guilds & 3 & 16.01 & $<0.0001$ \\
\hline Substratum type $\times$ Feeding guilds & 1 & 29.13 & $<0.0001$ \\
\hline Error & 19 & & \\
\hline
\end{tabular}

\section{Latitudinal distribution of $\mathrm{P} / \mathrm{B}$ ratios}

Along the North-South axis we observed a bimodal trend of annual P/B ratios (all taxa pooled, intertidal to $20 \mathrm{~m}$ depth, ANCOVA with mean annual temperature) with higher values at intermediate latitudinal classes for which data are available in each hemisphere $\left(20-40^{\circ} \mathrm{N}, 40-60^{\circ} \mathrm{N}\right.$ and $40-60^{\circ} \mathrm{S}$ latitudinal classes) than at high latitudes $\left(60-80^{\circ} \mathrm{S}\right)$ and low latitudinal $\left(40^{\circ} \mathrm{S}-20^{\circ} \mathrm{N}\right)$ ones (Fig. 2, Table 3). A bimodal trend in $\mathrm{P} / \mathrm{B}$ ratios was also observed for arthropods (data not shown), while no clear patterns were observed for the other main taxonomic groups, except for a decrease in the $\mathrm{P} / \mathrm{B}$ ratios of molluscs in the Northern Hemisphere (from 0-20 to $40-60^{\circ} \mathrm{N}$ ) (ANOVA, $F=3.40$, p = 0.0058; data not shown). The latter may influence the overall patterns of distribution in this hemisphere.

\section{Effect of taxonomic groups, substratum types and feeding guilds}

We observed higher production values for molluscs than for the other main taxa (Table 4). Arthropods showed the highest P/B ratios, followed by annelids, molluscs and echinoderms. Among functional guilds, high production values were observed for filter feeders and grazers and high $\mathrm{P} / \mathrm{B}$ ratios were observed for omnivores and predators (Table 4). Omnivores, deposit feeders, and predators showed low production values, and low $\mathrm{P} / \mathrm{B}$ ratio values were observed for filter and deposit feeders and grazers. Higher production was observed on hard than on soft substrata (sand and mud) and algae (including sediment with high organic enrichment), while $\mathrm{P} / \mathrm{B}$ ratios showed an inverse pattern (Table 4).

We observed a lower P/B ratio for mollusc filter feeders and grazers than for deposit feeders and omnivores (Fig. 3A, Table 3). A similar pattern was observed for annelids (Fig. 3B). Among substrata, we observed no effect on the mollusc P/B ratio, but there was a large effect of the annelid P/B ratio on algae (Fig. 3C, Table 3). Values associated with hard substrata showed a low annelid P/B ratio but generalization was impossible since data were from a single site (Bristol Channel, $41 \mathrm{~m}$ deep; George \& Warwick 1985). For arthropods, P/B ratios in sandy substrata were higher for predators than for other feeding guilds (Fig. 3D). A low arthropod P/B ratio in muddy substrata was observed for deposit feeders. On algae, the arthropod P/B ratios were high for grazers, while

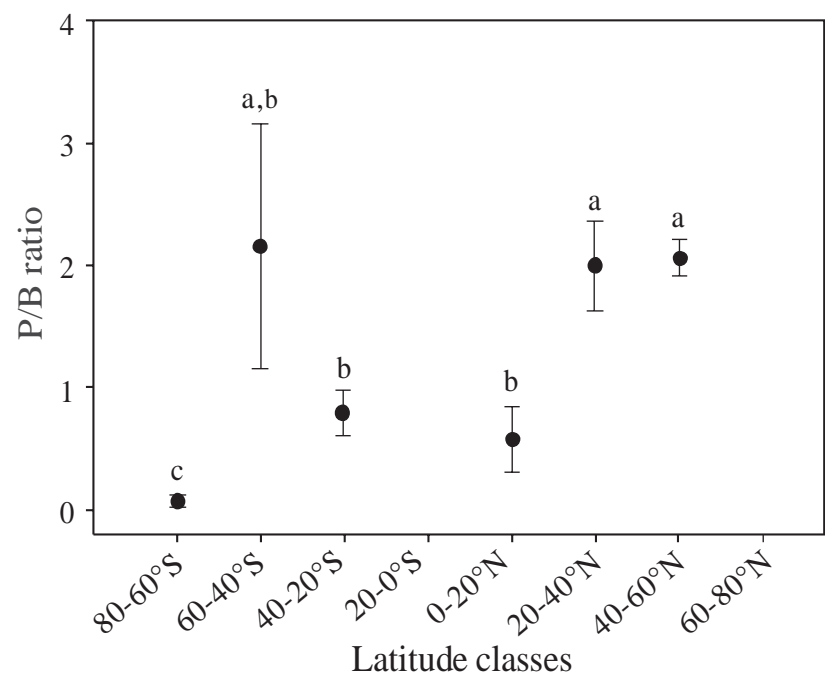

Fig. 2. Least-squares mean $\mathrm{P} / \mathrm{B}$ ratios $\left(\mathrm{yr}^{-1}\right)$ by latitudinal class (intertidal to $\leq 20 \mathrm{~m}$ depth). No data for classes 0 to $20^{\circ} \mathrm{S}$ and 60 to $80^{\circ} \mathrm{N}$ in this analysis. Error points are \pm SE. Different letters above points differ significantly 
Table 4. Mean $( \pm \mathrm{SE})$ annual production $\left(\log _{10}\right)$ and $\mathrm{P} / \mathrm{B}$ ratio for main taxonomic groups, functional guilds and substratum type (Algae: including sediment with high organic enrichment; Hard: mainly bedrock, but also including wood structures and boulders; Muddy and Sandy: dominant fraction)

\begin{tabular}{|lcc|}
\hline & $\begin{array}{c}\text { Mean production } \\
\left(\log _{10} \mathrm{~kJ} \mathrm{~m}^{-2} \mathrm{yr}^{-1}\right)\end{array}$ & $\begin{array}{c}\text { Mean P/B ratio } \\
\left(\mathrm{yr}^{-1}\right)\end{array}$ \\
\hline $\begin{array}{l}\text { Taxonomic group } \\
\text { Mollusca }\end{array}$ & $1.94 \pm 0.08(\mathrm{n}=227)$ & $1.77 \pm 0.14(\mathrm{n}=230)$ \\
Annelida & $1.42 \pm 0.09(\mathrm{n}=123)$ & $3.37 \pm 0.38(\mathrm{n}=120)$ \\
Arthropoda & $1.30 \pm 0.08(\mathrm{n}=140)$ & $4.85 \pm 0.31(\mathrm{n}=140)$ \\
Echinodermata & $1.34 \pm 0.23(\mathrm{n}=27)$ & $0.34 \pm 0.06(\mathrm{n}=28)$ \\
Functional guild & & \\
Deposit feeders (DF) & $1.47 \pm 0.09(\mathrm{n}=175)$ & $2.54 \pm 0.15(\mathrm{n}=175)$ \\
Filter feeders (FF) & $1.96 \pm 0.11(\mathrm{n}=134)$ & $1.82 \pm 0.20(\mathrm{n}=136)$ \\
Grazers (GR) & $1.64 \pm 0.08(\mathrm{n}=81)$ & $2.81 \pm 0.43(\mathrm{n}=82)$ \\
Omnivores (OM) & $1.25 \pm 0.11(\mathrm{n}=96)$ & $4.94 \pm 0.54(\mathrm{n}=95)$ \\
Predator (PR) & $1.37 \pm 0.13(\mathrm{n}=45)$ & $3.41 \pm 0.49(\mathrm{n}=42)$ \\
Substratum type & & \\
Algae & $1.10 \pm 0.15(\mathrm{n}=65)$ & $4.18 \pm 0.48(\mathrm{n}=62)$ \\
Hard & $2.21 \pm 0.16(\mathrm{n}=69)$ & $1.09 \pm 0.18(\mathrm{n}=70)$ \\
Muddy & $1.46 \pm 0.07(\mathrm{n}=219)$ & $3.25 \pm 0.21(\mathrm{n}=216)$ \\
Sandy & $1.67 \pm 0.08(\mathrm{n}=184)$ & $2.90 \pm 0.30(\mathrm{n}=188)$ \\
\hline
\end{tabular}

\section{Empirical models for production and $\mathrm{P} / \mathrm{B}$ ratios}

Our multivariate general models explained $92 \%$ of the production variance and up to $73 \%$ of the $\mathrm{P} / \mathrm{B}$ ratio variance (Table 5). Mean biomass explained a large part $(75 \%)$ of the variance in our general model of production. The regression coefficient for mean biomass (1.01; Table 5) was not significantly different from 1, indicating a proportional relationship between biomass and production and no significant effect of biomass on $\mathrm{P} / \mathrm{B}$ ratios. Our 2 general models retained nearly the same variables, except that temperature, which explained a low proportion of the variance, was retained for the general P/B ratios. Models for different taxonomic groups explained from 50 to $84 \%$ of the variation of $\mathrm{P} / \mathrm{B}$ ratios. Life span (maximum age of the population) was always retained in our regression models, and was negatively correlated to the production and $\mathrm{P} / \mathrm{B}$ ratios. Life span explained $17 \%$ of the production variance and was the variable that best explained the $\mathrm{P} / \mathrm{B}$ ratios' variance with a partial $\mathrm{R}^{2}$ ranging from 0.45 to 0.78 . Life span regression coefficients for amphipod, echinoderm and polychaete models were not significantly different from -1 . on hard substrata arthropod P/B ratios were low for the predators. A low $\mathrm{P} / \mathrm{B}$ ratio was observed for echinoderms, omnivores and predators on sandy substrata (Fig. 3E) but that result must not be generalized given the small dataset $(n=6)$ and number of study sites $(\mathrm{n}=2)$.

Table 5. Results of different multiple linear regression models (stepwise procedure) to estimate annual production $\left(\mathrm{kJ} \mathrm{m}^{-2} \mathrm{yr}^{-1}\right)$ and annual P/B ratio $\left(\mathrm{yr}^{-1}\right)$ in marine habitat. Life span (log transformed; $\left.\mathrm{yr}\right)$, mean body mass $\left(\log ; \mathrm{kJ}\right.$ ind. $\left.{ }^{-1}\right)$, water depth $(x+1$; $\mathrm{m})$, mean annual temperature $\left({ }^{\circ} \mathrm{C}\right)$, mean annual biomass $\left(\log _{;} \mathrm{kJ} \mathrm{m}^{-2}\right)$ and mesh size $(\mathrm{mm}$, not shown while always not significant) were the variables used in the regression models. Partial $\mathrm{R}^{2}$ below each regression coefficient $( \pm \mathrm{SE})$, ns: not significant, $\mathrm{N}=$ number of data included, Total $\mathrm{R}^{2}$, unbiased $\mathrm{R}^{2}$ from cross-validation method (see 'Methods' for details) to assess the accuracy of the multivariate relation and mean square errors (MSE) are shown. -: not included

\begin{tabular}{|c|c|c|c|c|c|c|c|c|c|}
\hline & Intercept & $\begin{array}{l}\text { Life span } \\
\quad(\log )\end{array}$ & $\begin{array}{c}\text { Mean body } \\
\text { mass } \\
(\log )\end{array}$ & $\begin{array}{l}\text { Water } \\
\text { depth } \\
(x+1)\end{array}$ & $\begin{array}{c}\text { Mean } \\
\text { annual } \\
\text { temperature }\end{array}$ & $\begin{array}{c}\text { Mean } \\
\text { biomass } \\
(\log )\end{array}$ & $\mathrm{N}$ & $\begin{array}{c}\text { Total } \mathrm{R}^{2} \\
(\text { Cross- } \\
\left.\text { validation } \mathrm{R}^{2}\right)\end{array}$ & MSE \\
\hline $\begin{array}{l}\text { General model Log }(\mathrm{P})= \\
\text { Partial } \mathrm{R}^{2}\end{array}$ & $0.45 \pm 0.05$ & $\begin{array}{l}-0.84 \pm 0.05 \\
0.16\end{array}$ & $\begin{array}{c}-0.09 \pm 0.02 \\
0.005\end{array}$ & ns & ns & $\begin{array}{l}1.01 \pm 0.02 \\
0.75\end{array}$ & 348 & $0.92(0.92)$ & 0.080 \\
\hline $\begin{array}{l}\text { General model Log }(\mathrm{P} / \mathrm{B})= \\
\text { Partial } \mathrm{R}^{2}\end{array}$ & $0.39 \pm 0.06$ & $\begin{array}{c}-0.86 \pm 0.05 \\
0.71\end{array}$ & $\begin{array}{c}-0.08 \pm 0.02 \\
0.01\end{array}$ & ns & $\begin{array}{c}0.007 \pm 0.003 \\
0.003\end{array}$ & - & 352 & $0.73(0.70)$ & 0.085 \\
\hline $\begin{array}{l}\text { Amphipoda Log }(\mathrm{P} / \mathrm{B})= \\
\text { Partial } \mathrm{R}^{2}\end{array}$ & $0.52 \pm 0.09$ & $\begin{array}{c}-1.17 \pm 0.10 \\
0.78\end{array}$ & $\begin{array}{c}-0.10 \pm 0.05 \\
0.01\end{array}$ & $\begin{array}{c}-0.003 \pm 0.001 \\
0.05\end{array}$ & ns & - & 57 & $0.84(0.80)$ & 0.017 \\
\hline $\begin{array}{l}\text { Bivalvia Log }(\mathrm{P} / \mathrm{B})= \\
\text { Partial } \mathrm{R}^{2}\end{array}$ & $0.47 \pm 0.06$ & $\begin{array}{c}-0.79 \pm 0.09 \\
0.63\end{array}$ & $\begin{array}{c}-0.12 \pm 0.02 \\
0.06\end{array}$ & ns & ns & - & 116 & $0.69(0.62)$ & 0.071 \\
\hline $\begin{array}{l}\text { Echinodermata Log }(\mathrm{P} / \mathrm{B})= \\
\text { Partial } \mathrm{R}^{2}\end{array}$ & $\begin{array}{c}-0.03 \pm 0.23 \\
\mathrm{~ns}\end{array}$ & $\begin{array}{c}-0.94 \pm 0.17 \\
0.47\end{array}$ & $\begin{array}{c}-0.19 \pm 0.07 \\
0.08\end{array}$ & ns & $\begin{array}{l}0.04 \pm 0.01 \\
0.23\end{array}$ & - & 26 & $0.78(0.67)$ & 0.086 \\
\hline $\begin{array}{l}\text { Gasteropoda Log }(\mathrm{P} / \mathrm{B})= \\
\text { Partial } \mathrm{R}^{2}\end{array}$ & $0.36 \pm 0.07$ & $\begin{array}{l}-0.71 \pm 0.11 \\
0.50\end{array}$ & ns & ns & ns & - & 43 & $0.50(0.46)$ & 0.086 \\
\hline $\begin{array}{l}\text { Polychaeta Log }(\mathrm{P} / \mathrm{B})= \\
\text { Partial } \mathrm{R}^{2}\end{array}$ & $\begin{array}{c}-0.03 \pm 0.19 \\
\mathrm{~ns}\end{array}$ & $\begin{array}{c}-0.95 \pm 0.15 \\
0.45\end{array}$ & ns & $\begin{array}{c}0.002 \pm 0.001 \\
0.05\end{array}$ & $\begin{array}{l}0.05 \pm 0.01 \\
0.06\end{array}$ & - & 64 & $0.55(0.52)$ & 0.089 \\
\hline
\end{tabular}



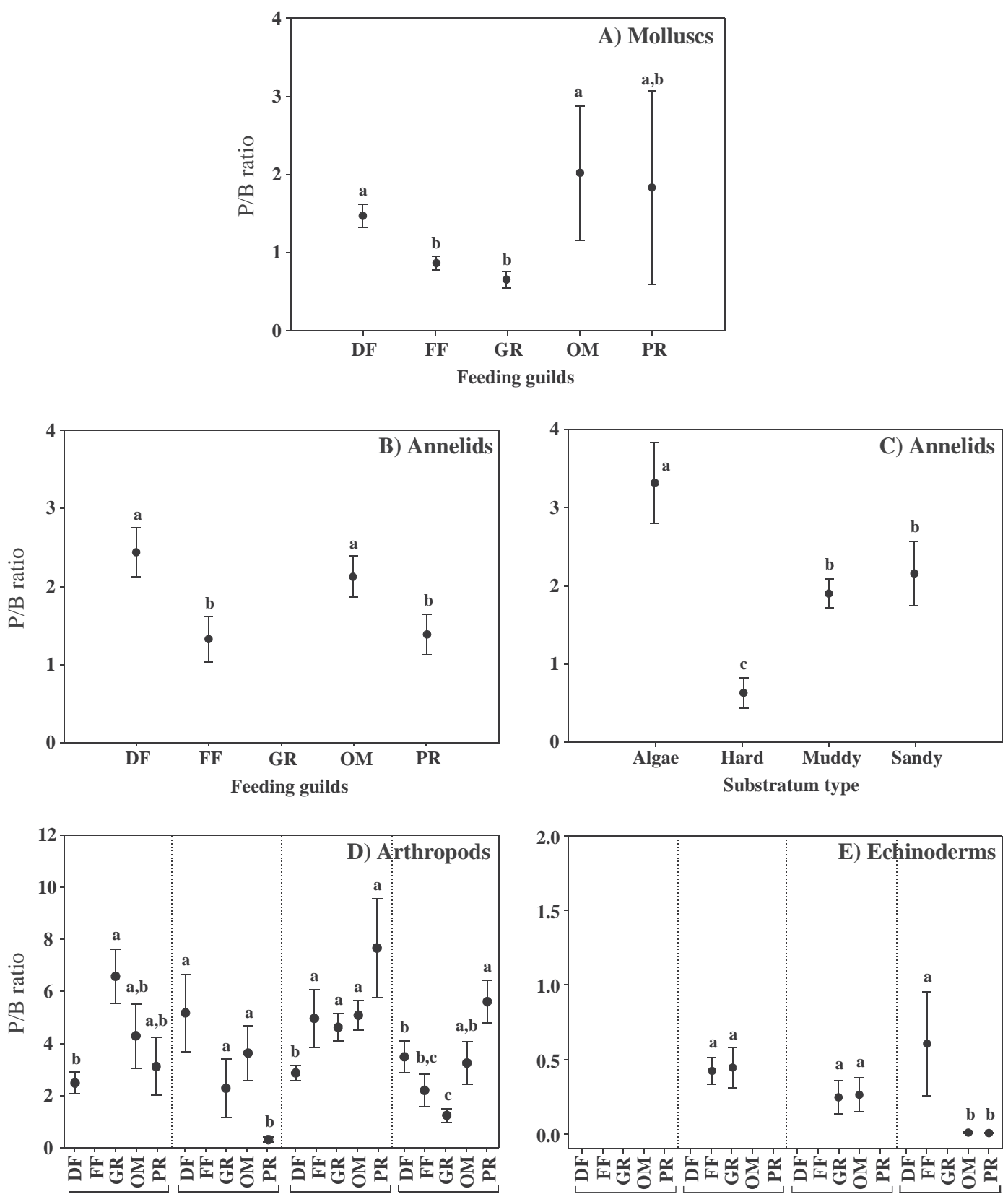

Fig. 3. Least-squares mean P/B ratios $\left(\mathrm{yr}^{-1}\right)$ for (A) molluscs by feeding guilds, (B) annelids by feeding guilds and (C) substratum type, (D) arthropods by feeding guilds for each substratum type and (E) echinoderms by feeding guilds for each substratum type. Feeding guilds: deposit feeders (DF); filter feeders (FF); grazers (GR); omnivores (OM) and predators (PR). Substratum type: Algae (including sediment with high organic enrichment); Hard (mainly bedrock, but also including wood structures and boulders); Muddy and Sandy substrata. Error points are \pm SE. Different letters above points differ significantly (note: in panels D and $\mathrm{E}$, differences are shown among feeding guilds for each substratum type)

Among taxon models, mean body mass, depth, and annual temperature were sometimes retained by the stepwise method. P/B ratios were always negatively related to body mass. Depth explained 5\% of amphipod and polychaete $\mathrm{P} / \mathrm{B}$ ratio variances. Temperature explained $23 \%$ and $5 \%$ of the $\mathrm{P} / \mathrm{B}$ ratio variance for echinoderms and polychaetes, respectively.
We observed a weak but significant effect of mesh size on the annual production and P/B ratio. Studies using a sieve mesh larger or equal to $0.5 \mathrm{~mm}$ had lower production values $(t=3.8 ; \mathrm{p}<0.0001)$ and lower P/B values $(t=6.11 ; \mathrm{p}<0.0001)$ than those using a smaller mesh size. Indeed, mesh size was included in the regressions but was never retained by the stepwise 
Table 6. Different multiple linear regression models (stepwise) for 4 depth and substratum categories to estimate $\mathrm{P} / \mathrm{B}$ ratio ( $\mathrm{yr}^{-1}$ ) in marine habitat using life span (log; yr), mean body mass $\left(\log ; \mathrm{kJ}\right.$ ind.$\left.^{-1}\right)$, water depth $(x+1 ; \mathrm{m})$, mean annual temperature $\left({ }^{\circ} \mathrm{C}\right)$ and mesh size $(\mathrm{mm})$. Partial $\mathrm{R}^{2}$ below each regression coefficient $( \pm \mathrm{SE}), \mathrm{N}=$ number of data included, total $\mathrm{R}^{2}$, unbiased $\mathrm{R}^{2}$ from cross-validation method (see text for details) to assess the accuracy of the multivariate relation and mean square errors (MSE) are shown. -: not included

\begin{tabular}{|c|c|c|c|c|c|c|c|c|c|}
\hline Depth/substratum & Intercept & $\begin{array}{l}\text { Life span } \\
\quad(\log )\end{array}$ & $\begin{array}{c}\text { Mean body } \\
\text { mass } \\
(\log )\end{array}$ & $\begin{array}{l}\text { Water } \\
\text { depth } \\
(x+1)\end{array}$ & $\begin{array}{c}\text { Mean } \\
\text { annual } \\
\text { temperature }\end{array}$ & $\begin{array}{l}\text { Mesh } \\
\text { size }\end{array}$ & $\mathrm{N}$ & $\begin{array}{c}\text { Total } \mathrm{R}^{2} \\
(\text { Cross- } \\
\left.\text { validation } \mathrm{R}^{2}\right)\end{array}$ & MSE \\
\hline $\begin{array}{l}\text { Intertidal Log }(\mathrm{P} / \mathrm{B})= \\
\text { Partial } \mathrm{R}^{2}\end{array}$ & $0.55 \pm 0.08$ & $\begin{array}{c}-0.89 \pm 0.11 \\
0.69\end{array}$ & $\begin{array}{c}-0.09 \pm 0.03 \\
0.02\end{array}$ & - & ns & ns & 107 & $0.71(0.69)$ & 0.084 \\
\hline $\begin{array}{l}0-20 \mathrm{~m} \log (\mathrm{P} / \mathrm{B})= \\
\text { Partial R }\end{array}$ & $0.73 \pm 0.09$ & $\begin{array}{c}-0.92 \pm 0.08 \\
0.77\end{array}$ & $\begin{array}{c}-0.10 \pm 0.02 \\
0.03\end{array}$ & $\begin{array}{c}-0.01 \pm 0.003 \\
0.01\end{array}$ & $\begin{array}{c}-0.01 \pm 0.005 \\
0.01\end{array}$ & ns & 142 & $0.80(0.80)$ & 0.056 \\
\hline $\begin{array}{l}21-50 m \log (\mathrm{P} / \mathrm{B})= \\
\text { Partial } \mathrm{R}^{2}\end{array}$ & $0.79 \pm 0.12$ & $\begin{array}{c}-0.84 \pm 0.05 \\
0.83\end{array}$ & ns & $\begin{array}{c}-0.01 \pm 0.004 \\
0.02\end{array}$ & $\mathrm{~ns}$ & ns & 48 & $0.84(0.82)$ & 0.041 \\
\hline $\begin{array}{l}51-930 \mathrm{~m} \text { Log }(\mathrm{P} / \mathrm{B})= \\
\text { Partial } \mathrm{R}^{2}\end{array}$ & $-0.49 \pm 0.18$ & $\begin{array}{c}-0.35 \pm 0.12 \\
0.76\end{array}$ & $\begin{array}{c}-0.20 \pm 0.04 \\
0.08\end{array}$ & ns & $\begin{array}{l}0.08 \pm 0.02 \\
0.05\end{array}$ & ns & 38 & $0.86(0.83)$ & 0.033 \\
\hline $\begin{array}{l}\text { Algae }^{\mathrm{a}} \log (\mathrm{P} / \mathrm{B})= \\
\text { Partial R }\end{array}$ & $0.84 \pm 0.06$ & $\begin{array}{c}-1.06 \pm 0.17 \\
0.46\end{array}$ & ns & $\begin{array}{c}-0.02 \pm 0.006 \\
0.19\end{array}$ & ns & ns & 24 & $0.65(0.53)$ & 0.043 \\
\hline $\begin{array}{l}\text { Hard Log }(\mathrm{P} / \mathrm{B})= \\
\text { Partial } \mathrm{R}^{2}\end{array}$ & $0.33 \pm 0.07$ & $\begin{array}{c}-0.62 \pm 0.09 \\
0.65\end{array}$ & $\begin{array}{c}-0.14 \pm 0.03 \\
0.09\end{array}$ & $\mathrm{~ns}$ & ns & ns & 53 & $0.74(0.71)$ & 0.053 \\
\hline $\begin{array}{l}\text { Muddy Log }(\mathrm{P} / \mathrm{B})= \\
\text { Partial } \mathrm{R}^{2}\end{array}$ & $0.36 \pm 0.06$ & $\begin{array}{c}-0.76 \pm 0.07 \\
0.61\end{array}$ & $\begin{array}{c}-0.11 \pm 0.03 \\
0.03\end{array}$ & ns & ns & $\begin{array}{c}0.03 \pm 0.01 \\
0.02\end{array}$ & 158 & $0.65(0.63)$ & 0.056 \\
\hline $\begin{array}{l}\text { Sandy Log }(\mathrm{P} / \mathrm{B})= \\
\text { Partial } \mathrm{R}^{2}\end{array}$ & $0.64 \pm 0.04$ & $\begin{array}{c}-1.09 \pm 0.06 \\
0.69\end{array}$ & ns & ns & ns & ns & 148 & $0.69(0.68)$ & 0.089 \\
\hline
\end{tabular}

methods except for the muddy substrate models (Table 6), where it was positively related to the P/B ratio but it explained a small part $(2 \%)$ of the variance.

Unbiased $\mathrm{R}^{2}$ values computed by the cross-validation methods were generally $3 \%$ lower than for the models fitted with full datasets (cf. Tables 5 \& 6) except for the echinoderms and algal substrate models. For these 2 models, unbiased $\mathrm{R}^{2}$ values were about $12 \%$ lower than for the models using full datasets, probably linked to the low number of observations on which these models were based.

\section{Production and $\mathrm{P} / \mathrm{B}$ ratios in relation to depth and habitat}

Depth was not retained in our production and P/B ratio general models (Table 5). It explained only $5 \%$ of the variation of $\mathrm{P} / \mathrm{B}$ ratio in models for amphipoda and polychaeta. However, when data from the shallow $(\leq 2 \mathrm{~m})$, intermediate $(21-50 \mathrm{~m})$ or deep $(>51 \mathrm{~m})$ subtidal zones were considered in multivariate regression models, depth was not retained (stepwise method) for the deep zone but explained a small part (1 and $2 \%$, respectively) of the P/B ratio variance for shallow and intermediate subtidal zones (Table 6). Although depth classes stratified the data, biotic variables still explained a large part of the $\mathrm{P} / \mathrm{B}$ ratio variance for each depth category. Indeed, P/B ratio variances were still best explained by life span. The latter explained $69 \%$ of the variance in the intertidal zone and explained 78 , 83 and $76 \%$, respectively of the P/B ratio variance at the 3 depth classes examined (shallow, intermediate and deep zones). Temperature alone explained a small part of the P/B ratio variation $(F=15.48$; p $<0.001$; $\left.\mathrm{R}^{2}=0.028\right)$. However, temperature was retained in the multiple regressions as a significant factor in the shallow and deep subtidal zones, but it still explained little of the P/B ratio variance (1 and 5\%, respectively; see Table 6).

\section{Differences among published models}

We explored the differences among published empirical models of production using marine datasets (Table 7). The lower MSE of the residual (observed data minus predicted production) showed that Brey's (2004) model was the best to predict our production dataset, followed by those of Robertson (1979), Brey (1990) and Tumbiolo \& Downing (1994). However, paired comparisons between models using a dependent coefficient test (Neill \& Dunn 1975, Steiger 1980) showed that Robertson's model was slightly better at explaining observed production than Brey's (2004) model $(t=2.40 ; \mathrm{p}=0.016 ; \mathrm{n}=353)$. Nevertheless, with 
an $\mathrm{R}^{2}$ ranging from 0.78 to 0.89 , all models successfully predicted our observed production values. An examination of the residuals showed that only Brey's (1990) model slightly underestimated the production, while all the others overestimated production. This overestimation reached a mean factor of 10 for Tumbiolo \& Downing's model.

\section{DISCUSSION}

The annual production and $\mathrm{P} / \mathrm{B}$ ratios varied substantially among marine taxa, functional guilds and habitats, and their relationship with biotic variables changed with taxa and habitats. Their patterns were related to the life history of the species present. P/B ratios are known to be closely related to life span (as voltinism) (e.g. Zaïka 1970, Mann 1976, Waters 1977) and not necessarily directly related to environmental factors, except in the manner that environment affects voltinism (Waters 1977), which determines life span. Trends among substrata and functional guilds reveal complex interactions that could be also explained by the habitat 'quality' (quantity and quality of food) as well as suitable refuges. In addition, life span, an intrinsic characteristic of any given population in a given environment, was more important than body mass, temperature or depth to describe global variation in annual P/B ratios.

\section{Quality and representativeness of the dataset}

Annual production data from the literature should be used with caution (Rigler \& Downing 1984, Benke 1993). Production data without strict selection have been used to increase the size of datasets (e.g. Brey 1990, 1999a, Benke 1993), with the assumption that residual errors were distributed close to the true value. The choice of high quality journals used in this study, while ensuring high quality of production studies, cannot ensure their accuracy. The limited dataset for certain latitudes and depths are useful as they reflect reality (see Brey 1999b). Strictly speaking, multiple regression analysis should use dependent variables that have been derived from predictor variables. It may be argued that most empirical relations predicting annual secondary production (or P/B ratio) use mean annual biomass and mean body mass, which are used to estimate production, and thus they are not strictly independent. However, such empirical relationships can be useful providing that care is taken when interpreting the results (see similar relationships between respiration and production: McNeill \& Lawton 1970, Humphreys 1979).

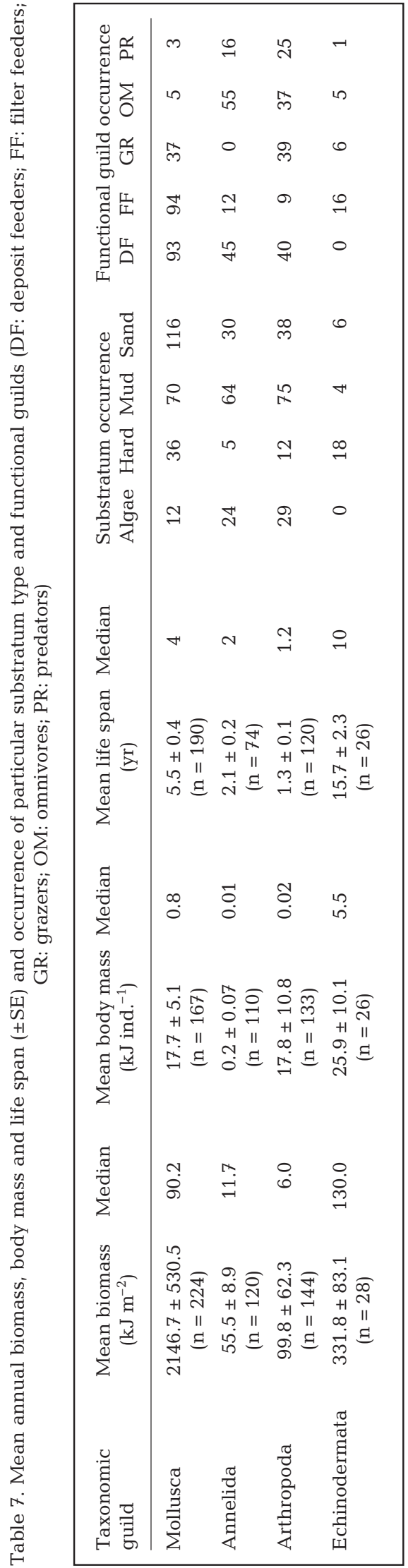




\section{Latitudinal distribution of $\mathrm{P} / \mathrm{B}$ ratios}

Low values of $\mathrm{P} / \mathrm{B}$ ratios in shallow regions at low and high latitudes (i.e. 60 to $80^{\circ} \mathrm{S}$ ) probably reflect the rigorous environmental conditions. In the Antarctic region, food (quality and quantity) produced is very small and variable (Clarke \& Leakey 1996) and the very low temperature is a factor that limits metabolic processes (Brockington \& Clarke 2001) (see also Clarke 1980, Arntz et al. 1994). In this region the low P/B ratios were fully explained by temperature and depth (Brey \& Clarke 1993). We still observed a low mean $\mathrm{P} / \mathrm{B}$ ratio for this region after extracting the temperature effect (as covariate) and focussing on shallow regions. Our data from Antarctica included echinoderms with high body mass values and other taxa with long developmental periods (mean life span $=27.3 \mathrm{yr} ; F=4.98 ; \mathrm{p}=0.0002$ ) both larger and longer respectively than for any other latitudinal class, which may explain the low annual production and P/B ratios observed (see also Brey \& Clarke 1993 for temperature and depth effects). Most values from 40 to $20^{\circ} \mathrm{S}$ were from filter feeding molluscs with high mean annual biomass values and relatively low $\mathrm{P} / \mathrm{B}$ ratios. Indeed, high intertidal community biomass values in the 40 to $20^{\circ} \mathrm{S}$ latitudinal classes have been observed (Ricciardi \& Bourget 1999). A strong gradient from high $\mathrm{P} / \mathrm{B}$ ratios in tropical regions to low $\mathrm{P} / \mathrm{B}$ ratios in temperate regions has been reported in the Northern Hemisphere (see Ansell et al. 1978), while others argued that there is little variation in P/B ratios between these regions (Alongi 1990, Riddle et al. 1990). However, our results do not support such trends, except for mollusc P/B ratios.

\section{Life history: a determinant for $\mathrm{P} / \mathrm{B}$ ratios among taxa, substrata and functional guilds}

General trends of production and P/B ratios among categories indicate the strong impact of life histories (i.e. long life span, large body mass) of species. Both production and $\mathrm{P} / \mathrm{B}$ ratios were negatively affected by life span and body mass. Proportionally, large individuals use more energy for respiration than for growth (Waters 1977, Banse \& Mosher 1980, see Peters 1983 for theoretical background) which explains why somatic $\mathrm{P} / \mathrm{B}$ ratios decrease with age and body mass and are high in populations dominated by young cohorts (e.g. Warwick 1980, Sarda et al. 2000) since younger individuals invest more energy in growth and older individuals invest more in reproduction. Species with a high P/B ratio are generally fast-growing with small body mass (Brey 1999b). In contrast, species with high biomass, large body mass and long life span (e.g. molluscs and echinoderms, Table 7) display low mean annual P/B ratios. Indeed, the observed low mollusc $\mathrm{P} / \mathrm{B}$ ratios for filter feeders and grazers may be explained by the high body mass and long life span. Mollusc filter feeders (e.g. mussels) had a slow growth that could be limited by the input of planktonic food (Asmus \& Asmus 1990). Among functional guilds, high production values were observed for filter feeders (mostly molluscs) and high $\mathrm{P} / \mathrm{B}$ ratios were observed for omnivores and predators (dominated by annelids and arthropods with short life spans and small body mass, Table 7). Most arthropods (mainly represented by amphipods) are motile, which could enhance their metabolism and P/B ratios. In general, the P/B ratios of mobile species were higher than for non-motile ones (means of $3.7 \pm 0.23$ and $2.1 \pm$ $0.15 \mathrm{yr}^{-1}$ respectively; ANOVA; $F=33.07$; $p<0.0001$ ). This result is partly explained by lower mean values of body mass for mobile than for non-mobile species (mean $\log _{10}$ of $-0.38 \pm 0.1$ vs. $-1.37 \pm 0.1 \mathrm{~kJ}$ ind. ${ }^{-1}$; ANOVA; $F=62.94 ; \mathrm{p}<0.0001)$. This result was suspected (Brey \& Clarke 1993) and was observed for crustaceans with high swimming capacities (i.e. suprabenthos) (Cartes et al. 2002). The known explanations for the difference between $\mathrm{P} / \mathrm{B}$ ratios of filter feeders and predators are contradictory. Higher absorption efficiency has been observed for carnivores (marine and terrestrial) than for detritus-feeder isopods, which may reflect access to higher food quality (Willows 1987) and also explain the high $\mathrm{P} / \mathrm{B}$ ratios for predators. However, in freshwater stream macrobenthos, high $\mathrm{P} / \mathrm{B}$ ratios were observed for predators, although a broad range of values has been noted, with some predators having low values of annual production due to relative long life spans and large body mass (Benke 1993). The observed low arthropod $\mathrm{P} / \mathrm{B}$ ratios for predators on hard substrata (cf. Fig. 3D) were related to species with few individuals with a high body mass (e.g. Panulirus homarus; Berry \& Smale 1980).

Algae is a substratum offering high concentrations of food (Summerson \& Peterson 1984, Vetter 1995) as well as increased niches and refuges against predators (Pihl 1986, Vetter 1998). The high 'quality' of this habitat offering a better protection of juveniles might explain the high $\mathrm{P} / \mathrm{B}$ ratios observed on this substratum. High benthic biomass, production and $\mathrm{P} / \mathrm{B}$ ratio values were observed in areas colonized by marine angiosperms (e.g. Zostera marina L.) (Pihl 1986, Asmus \& Asmus 1990, Edgar \& Shaw 1995). Our dataset from organic substrata (including macrophyte algae, $\mathrm{n}=62$ ) confirms a trend detected by Tumbiolo \& Downing (1994) with a limited dataset ( $\mathrm{n}=11$ for algae). Algal structures might enhance larval settlement by locally affecting hydrodynamics (Woodin 1978, Butman 1987), offering refuges or additional microhabitats that can offer protection against predation (Orth 1975, Summerson \& Peterson 1984) and increase sediment 
stability and protection against high energy bursts (Paterson \& Black 1999). These may result in low juvenile mortality and a high growth rate, and contribute to high P/B ratios (e.g. annelids, mainly deposit feeders and omnivores) as well as for arthropod grazers of the algal substrate (see Fig. 3B-D). In stream benthos, high P/B ratios have also been related to the availability of high food quality (organic deposition or periphyton) for scrapers (associated to the grazers guild) (Benke 1993). Low P/B ratios for marine crustacean deposit feeders have been explained by their consumption of more refractory food material with low nutritional value (Cartes et al. 2002).

Hard bottoms are often high-energy environments enhancing food supply for filter feeders (Gili \& Coma 1998) and are known to support high biomass (Ricciardi \& Bourget 1999). Molluscs and echinoderms (high biomass, large body mass and long life spans) dominate on hard bottoms, possibly explaining the low overall P/B ratios observed on this substratum. Patterns in production and $\mathrm{P} / \mathrm{B}$ ratios were comparable between sandy and muddy habitats and suggest that within the soft bottom community differences are better explained by life history characteristics rather than substratum quality differences (e.g. grain size, $\%$ organic matter). Despite the positive correlation between grain size and growth (Grizzle \& Lutz 1989) no particular relationship was observed among sediment type or body size spectra (Parry et al. 1999). No patterns were observed in $\mathrm{P} / \mathrm{B}$ ratios within mud habitats, in either freshwater or marine environments (Lopez 1988).

\section{Multiple regression models}

In our general model for macroinvertebrate production, the regression coefficient for biomass was close to 1 , while there was no relationship between P/B ratios and biomass. Similar results have been observed for aquatic habitats in general (Brey 1990, 2004), for marine (Tumbiolo \& Downing 1994) as well as for running waters (Morin 1992) but not for lake models (see Plante \& Downing 1989). Life span is the most important biotic variable explaining the variations in $\mathrm{P} / \mathrm{B}$ ratio. We observed, for amphipods, a regression coefficient for life span significantly higher than all other models except for the polychaete and echinoderm models (Table 5). Thus, for this taxa, the variations in P/B ratio were probably more controlled by the life span than for the other taxa. Even though life span values for amphipods were the shortest (from 0.31 to $2 \mathrm{yr}$ ) of all of our taxonomic regression models, the amphipod model explained the largest percentage of the variation in $\mathrm{P} / \mathrm{B}$ ratio.
Life span (maximum observed age in a population) has been used alone in some empirical models (e.g. Zaïka 1970, Warwick 1980, Parsons et al. 1984, Etim \& Brey 1994) and explained up to $70 \%$ of the variance of production or $\mathrm{P} / \mathrm{B}$ ratios. Population life span is not a preferred variable to include in empirical models to predict production because it is difficult to estimate due to predation (or intensive exploitation) (see Brey 1990, Tumbiolo \& Downing 1994). For many taxa, predicting age limits may be difficult but our results clearly show that the realized life span is a determinant variable for production or P/B ratio predictions. Information on population life span was available in more than $75 \%$ of the papers included in our analysis.

In all our models, except for echinoderms and the depth category (51 to $930 \mathrm{~m}$ ) models, the coefficients associated with mean body mass were significantly lower than the theoretical general allometric coefficient $(-0.25)$ predicted by body size (Peters 1983, Calder 1984). Although a departure from this general allometric coefficient has been observed in some studies (Banse \& Mosher 1980, Plante \& Downing 1989), many other investigations (e.g. Schwinghamer et al. 1986, Brey 1990b, Morin \& Bourrassa 1992, Benke 1993, Urban \& Campos 1994) reported coefficients for body mass equal to -0.25 . It has been argued that maximum body mass is a more suitable variable for predictive models because it is more stable among populations than life span (Tumbiolo \& Downing 1994). This is probably true but we consider that life span could be a better predictor of the observed field production instead of the potential production (productivity sensu Davis 1963, Crisp 1984) that refers to production under the theoretical steady-state conditions. In addition, mean body mass is more suitable than maximum body mass to predict $\mathrm{P} / \mathrm{B}$ ratio since it explained more of the $\mathrm{P} / \mathrm{B}$ ratio variance $\left(\mathrm{R}^{2}=0.43 \mathrm{vs} . \mathrm{R}^{2}=0.21\right.$ respectively) alone. Mean body mass was always preferred in regression analysis (stepwise method). The same trends were observed for a running water environment (Morin \& Bourrassa 1992). Studies using sieves $<0.5 \mathrm{~mm}$ retain smaller individuals than coarser sieves. These cohorts of young individuals contribute to increased overall production due to their fast growth, which is reflected in higher values of $\mathrm{P} / \mathrm{B}$ ratios. The variable mesh size was not retained in all of our regression models (except for data on muddy substratum) as was found by Cartes et al. (2002) with suprabenthos data.

\section{Differences among models}

We compared our general model of production with 4 other models. The Tumbiolo \& Downing (1994) model 
Table 8. Models of annual macrobenthic production from the literature, $\mathrm{R}^{2}$ (number of data originally included), residuals $( \pm \mathrm{SE}$ ) computed by $\log \mathrm{P}$ (observed) - $\log \mathrm{P}$ (corresponding model) when fitted with our dataset and corresponding mean square error (MSE). Mass units are g Dry Weight (DW) for Robertson's models; g Ash-free Dry Weight (AFDW) for Brey (1990); $g$ DW for Tumbiolo \& Downing (1994) and kilojoules (kJ) for Brey (2004). B: mean annual biomass (mass m $\left.{ }^{-2}\right) ;$ A: life span (yr); $\mathrm{W}_{\text {mean }}$ mean body mass (mass ind); T: mean annual temperature $\left({ }^{\circ} \mathrm{C}\right)$; $\mathrm{D}$ : site depth $(\mathrm{m}$; intertidal $=1)$; Dummy variable $($ no $=0$, yes $=1)$ for: subtidal species (Dsubt); infauna (Dinf); motile epifauna (Dmoti); Annelida or Crustacea (DM); Echinodermata (Dechi); Insecta (Dinse)

\begin{tabular}{|c|c|c|c|c|}
\hline \multirow{2}{*}{$\begin{array}{l}\text { Source }\left(\mathrm{R}^{2}, \text { number }\right. \\
\text { of data included) }\end{array}$} & \multirow[t]{2}{*}{ Model } & \multicolumn{3}{|c|}{ Adjustment with our data } \\
\hline & & Residuals & $\mathrm{R}^{2}$ & MSE \\
\hline $\begin{array}{l}\text { Robertson (1979) } \\
(0.70,49)\end{array}$ & $\log \mathrm{P}=0.66+\log \mathrm{B}-0.726 \log \mathrm{A}$ & $-0.184 \pm 0.018$ & 0.89 & $\begin{array}{c}0.156 \\
(\mathrm{n}=399)\end{array}$ \\
\hline $\begin{array}{l}\text { Brey }(1990)^{\mathrm{a}} \\
(0.85,337)\end{array}$ & $\log \mathrm{P}=-0.473+1.007 \log \mathrm{B}-0.274 \log \mathrm{W}_{\text {mean }}$ & $0.047 \pm 0.020$ & 0.84 & $\begin{array}{c}0.174 \\
(\mathrm{n}=442)\end{array}$ \\
\hline $\begin{array}{l}\text { Tumbiolo \& Downing (1994) } \\
(0.86,125)\end{array}$ & $\log \mathrm{P}=0.24+0.96 \log \mathrm{B}-0.21 \log \mathrm{W}_{\max }+0.03 \mathrm{~T}-0.16 \log (\mathrm{D}+1)$ & $-1.098 \pm 0.027$ & 0.78 & $\begin{array}{c}1.457 \\
(\mathrm{n}=352)\end{array}$ \\
\hline $\begin{array}{l}\text { Brey }(2004)^{\mathrm{a}} \\
(0.77,1102)\end{array}$ & $\begin{array}{l}\log \mathrm{P}=7.947+\log \mathrm{B}-2.294 \log \mathrm{W}_{\text {mean }}-2409.856(1 / \mathrm{T}+273)+ \\
0.168(1 / \mathrm{D})+0.194 \mathrm{Dsubt}+0.180 \mathrm{Dinf}+0.277 \mathrm{Dmoti}+ \\
0.174 \mathrm{DM}-0.188 \text { Dechi+ 0.330 Dinse }+582.851 \log \mathrm{W}_{\text {mean }}(1 / \mathrm{T}+273)\end{array}$ & $-0.018 \pm 0.018$ & 0.87 & $\begin{array}{c}0.145 \\
(\mathrm{n}=434)\end{array}$ \\
\hline
\end{tabular}

explained our observed production well but was less efficient than the other models (Table 8). The Tumbiolo \& Downing model, which included mean annual biomass, maximum body mass, mean annual surface temperature and depth, was built to improve the predictions of the Brey's (1990) model based on high and low values for water temperature and depth. The use of a larger dataset and a larger depth range did not show that depth was an important factor in comparison to life span and body mass, especially using deeper sites. Surprisingly, the Robertson (1979) and Brey (2004) models were able to predict our observed production better than their own dataset (cf. Table 8), even if Brey's (2004) model included freshwater benthos. The strategy of using such dummy variables in the equation (i.e. 0, 1; Table 8) associated with presence or absence of a given variable (e.g. species: annelida, molluscs, echinoderms; or characteristics: subtidal, epifauna, motility) may lead to increased accuracy in an empirical equation.

Water depth explained a marginal portion of the P/B ratios and was not retained by our model for deepwater areas. Thus, empirical models using depth should be used with caution. However, empirical methods allow the generation of new hypotheses and approximate comparisons between communities from different sites or habitats, and may help to assess community production with limited field data for rare species or those with unknown dynamics. An interesting direction to improve empirical equations could be the incorporation of environmental variables on ecosystem productivity (see comments in Tumbiolo \& Downing 1994) that are known to affect nearshore macrobenthic biomass and growth, such as primary production (Nixon \& Buckley 2002, Bourget et al. 2003) or a wave exposure index (e.g. Bustamante \& Branch 1996, Ricciardi \& Bourget 1999, McQuaid \& Lindsay 2000). These variables are likely to explain a small additional part of the variance in annual production given that most has already been accounted for.

Acknowledgements. We would like to thank G. Daigle and H. Crépeau of the Service de consultation statistique (Département de mathématiques et statistique, Université Laval) for statistical advice. We are grateful to A. Ricciardi, W. F. Vincent and R. D. Hedger for comments on an earlier draft of this manuscript and to T. Brey for stimulating discussions on statistical approach. We also thank the 4 anonymous reviewers for their constructive comments. Financial support was provided by grants from NSERC and FCAR to E.B. and scholarships from FCAR, Québec-Océan and Fondation de l'Université Laval to M.C.

\section{LITERATURE CITED}

Alongi DM (1990) The ecology of tropical soft-bottom benthic ecosystems. Oceanogr Mar Biol Annu Rev 28:381-496

Ansell AD, McLusky DS, Stirling A, Trevallion A (1978) Production and energy flow in the macrobenthos of two sandy beaches in South West India. Proc R Soc Edinb 76: 269-296

Arntz WE, Brey T, Gallardo VA (1994) Antarctic zoobenthos. Oceanogr Mar Biol Annu Rev 32:241-304

Asmus H, Asmus RM (1990) Trophic relationships in tidal flat areas: to what extent are tidal flats dependent on imported food? Neth J Sea Res 27:93-100

Attrill M, Stafford R, Rowden A (2001) Latitudinal diversity patterns in estuarine tidal flats: indications of a global cline. Ecography 24:318-324

Banse K, Mosher S (1980) Adult body mass and annual production/biomass relationships of field populations. Ecol Monogr 50:355-379

Barnes RD (1987) Invertebrate zoology. Saunders College, Philadelphia, PA

Bayne BL, Worrall CM (1980) Growth and production of 
mussels Mytilus edulis from two populations. Mar Ecol Prog Ser 3:317-328

Benke AC (1993) Concepts and patterns of invertebrate production in running waters. Verh Int Ver Limnol 25: 15-38

Berry PF, Smale MJ (1980) An estimate of production and consumption rates in the spiny lobster Panulirus homarus on a shallow littoral reef off the Natal coast, South Africa. Mar Ecol Prog Ser 2:337-343

Bourget E, Ardisson PL, Lapointe L, Daigle G (2003) Environmental factors as predictors of epibenthic assemblage biomass in the St. Lawrence system. Estuar Coast Shelf Sci $57: 641-652$

Brey T (1986) Fomalin and formaldehyde-depot chemicals: effects on dry weight and ash free dry weight of two marine bivalve species. Meeresforschung 31:52-57

Brey T (1990) Estimating productivity of macrobenthic invertebrates from biomass and mean individual weight. Meeresforschung 32:329-343

Brey T (1999a) A collection of empirical relations for use in ecological modelling. ICLARM Quart 22:24-28

Brey T (1999b) Growth performance and mortality in aquatic benthic invertebrates. Adv Mar Biol 35:153-223

Brey T (2004) Empirical relations in aquatic populations. In: Population Dynamics in Benthic Invertebrates: A virtualhandbook. www.awi-bremerhaven.de/Benthic/Ecosystem/ FoodWeb/Handbook/main.html. Alfred Wegener Institute, Bremerhaven

Brey T, Clarke A (1993) Population dynamics of marine benthic invertebrates in Antarctic and subantarctic environments: are there unique adaptations? Antarct Sci 5: 253-266

Brey T, Gerdes D (1997) Is Antarctic benthic biomass really higher than elsewhere? Antarct Sci 9:266-267

Brey T, Hain S (1992) Growth, reproduction and production of Lissarca notorcadensis (Bivalvia: Philobryidae) in the Weddell Sea, Antarctica. Mar Ecol Prog Ser 82:219-226

Brockington S, Clarke A (2001) The relative influence of temperature and food on the metabolism of a marine invertebrate. J Exp Mar Biol Ecol 258:87-99

Bustamante RH, Branch GM (1996) Large-scale patterns and trophic structure of southern African rocky shores: the roles of geographic variation and wave exposure. J Biogeogr 23:339-351

Butman CA (1987) Larval settlement of soft-sediment invertebrates: the spatial scales of pattern explained by active habitat selection and the emerging role of hydrodynamical processes. Oceanogr Mar Biol Annu Rev 25:113-165

Calder WA (1984) Size, function, and life history. Harvard University Press, Cambridge, MA

Cartes J, Brey T, Sorbe J, Maynou F (2002) Comparing production-biomass ratios of benthos and suprabenthos in macrofaunal marine crustaceans. Can J Fish Aquat Sci 59: $1616-1625$

Clarke A (1980) A reappraisal of the concept of metabolic cold adaptation in polar marine invertebrates. Biol J Linn Soc 14:77-92

Clarke A, Leakey RJG (1996) The seasonal cycle of phytoplankton, macronutrients, and the microbial community in a nearshore Antarctic marine ecosystem. Limnol Oceanogr 41:1281-1294

Crisp DJ (1984) Energy flow measurements. In: Holme NA, McIntyre AD (eds) Methods for the study of marine benthos. Blackwell Scientific Publications, Oxford, p 284-372

Culver SJ, Buzas MA (2000) Global latitudinal species diversity gradient in deep-sea benthic foraminifera. Deep-Sea Res 47:259-275
Davis CC (1963) On questions of production and productivity in ecology. Arch Hydrobiol 59:145-161

Edgar GJ (1990) The use of the size structure of benthic macrofaunal communities to estimate faunal biomass and secondary production. J Exp Mar Biol Ecol 137:195-214

Edgar GJ, Shaw C (1995) The production and trophic ecology of shallow-water fish assemblages in southern Australia. J Exp Mar Biol Ecol 194:107-131

Etim L, Brey T (1994) Growth, productivity, and significance for fishery of the bivalve Egeria radiata (Donacidea) in the Cross river, Nigeria. Arch Fish Mar Res 42:63-75

Flach E, de Bruin W (1999) Diversity patterns in macrobenthos across a continental slope in the NE Atlantic. J Sea Res 42:303-323

Fréchette M, Bourget E (1985) Food-limited growth of Mytilus edulis $\mathrm{L}$. in relation to the benthic boundary layer. Can J Fish Aquat Sci 42:1166-1170

George CL, Warwick RM (1985) Annual macrofauna production in a hard-bottom reef community. J Mar Biol Assoc UK 65:713-735

Gili JM, Coma R (1998) Benthic suspension feeders: their paramount role in littoral marine food webs. TREE 13: 316-324

Gray JS (2001) Antarctic marine benthic biodiversity in a world-wide latitudinal context. Polar Biol 24:633-641

Gray JS (2002) Species richness of marine soft sediment. Mar Ecol Prog Ser 244:285-297

Grizzle RE, Lutz RA (1989) A statistical model relating horizontal seston fluxes and bottom sediment characteristics to growth of Mercenaria mercenaria. Mar Biol 102:95-105

Hillebrand H (2004) Strength, slope and variability of marine latitudinal gradients. Mar Ecol Prog Ser 273:251-267

Humphreys WF (1979) Production and respiration in animal populations. J Anim Ecol 48:427-453

Littorin B, Gilek M (1999) Vertical patterns in biomass, size structure, growth and recruitment of Mytilus edulis in an archipelago area in the northern Baltic Sea proper. Ophelia 50:93-112

Lopez GR (1988) Comparative ecology of the macrofauna of freshwater and marine muds. Limnol Oceanogr 33: 946-962

Macpherson E (2002) Large-scale species-richness gradients in the Atlantic Ocean. Proc R Soc Lond 269:1715-1720

Mann KH (1976) Production on the bottom of the sea. In: Cushing DH, Walsh JJ (eds) The ecology of the seas. Blackwell Scientific Publications, Oxford, p 225-250

McNeill J, Lawton JH (1970) Annual production and respiration in animal populations. Nature 225:472-474

McQuaid CD, Lindsay TL (2000) Effect of wave exposure on growth and mortality rates of the mussel Perna perna: bottom-up regulation of intertidal populations. Mar Ecol Prog Ser 206:147-154

Milliken GA, Johnson DE (1984) Analysis of messy data. Lifetime Learning Publications, Belmont, CA

Montgomery DC (1991) Design and analysis of experiments. John Wiley \& Sons, Toronto

Morin A, Bourrassa N (1992) Modèle empirique de la production annuelle et du rapport P/B d'invertébrés benthiques d'eau courante. Can J Fish Aquat Sci 49:532-539

Nakaoka M (1992) Spatial and seasonal variation in growth rate and secondary production of Yoldia notabilis in Otsuchi Bay, Japan, with reference to the influence of food supply from the water column. Mar Ecol Prog Ser 88: 215-223

Neill JJ, Dunn OJ (1975) Equality of dependent correlation coefficients. Biometrics 31:531-543

Nixon S, Buckley B (2002) 'A strikingly rich zone' - nutrient 
enrichment and secondary production in coastal marine ecosystems. Estuaries 25:782-796

Orth RJ (1975) Destruction of eelgrass Zostera marina by the Cownose Ray Rhinoptera bonasus in the Chesapeake Bay. Chesapeake Sci 16:205-208

Parry DM, Kendall MA, Rowden AA, Widdicombe S (1999) Species body size distribution patterns of marine benthic macrofauna assemblages from contrasting sediment types. J Mar Biol Assoc UK 79:793-801

Parsons TR, Takahashi M, Hargrave B (1984) Biological oceanographic processes. Pergamon Press, Oxford

Paterson DM, Black KS (1999) Water flow, sediment dynamics and benthic ecology. In: Nedwell DB, Raffaelli DG (eds) Advances in ecological research: estuaries, Vol 29. Academic Press, San Diego, CA, p 155-193

Pechenik JA (1995) Biology of the invertebrates. Prindle Weber \& Schmidt, Boston, MA

Peters RH (1983) The ecological implications of body size. Cambridge University Press, Cambridge

Pihl L (1986) Exposure, vegetation and sediment as primary factors for mobile epibenthic faunal community structure and production in shallow marine soft bottom areas. Neth J Sea Res 20:75-83

Plante C, Downing JA (1989) Production of freshwater invertebrate populations in lakes. Can J Fish Aquat Sci 46: 1489-1498

Rex MA, Stuart CT, Hessler RR, Allen JA, Sanders HL, Wilson GDF (1993) Global-scale latitudinal patterns of species diversity in the deep-sea benthos. Nature 365:636-639

Ricciardi A, Bourget E (1998) Weight-to-weight conversion factors for marine benthic macroinvertebrates. Mar Ecol Prog Ser 163:245-251

Ricciardi A, Bourget E (1999) Global patterns of macroinvertebrate biomass in marine intertidal communities. Mar Ecol Prog Ser 185:21-35

Riddle MJ, Alongi DM, Dayton PK, Hansen JA, Klumpp DW (1990) Detrital pathway in a coral reef lagoon. I. Macrofaunal biomass and estimates of production. Mar Biol 104: 109-118

Rigler FH, Downing JA (1984) The calculation of secondary production. In: Downing JA, Rigler FH (eds) A manual on methods for the assessment of secondary productivity in fresh waters. Blackwell Scientific Publications, Oxford, p 19-86

Robertson AI (1979) The relationship between annual production: biomass ratios and lifespans for marine macrobenthos. Oecologia 38:193-202

Sarda R, Pinedo S, Dueso A (2000) Estimating secondary production in natural populations of polychaetes: some general constraints. Bull Mar Sci 67:433-447

Editorial responsibility: Otto Kinne (Editor-in-Chief), Oldendorf/Luhe, Germany
SAS Institute (1999) SAS OnlineDoc ${ }^{\circledR}$, Version 8. SAS Institute, Cary, NC

Scherrer B (1984) Biostatistique. Gaëtan Morin, Montréal

Schwinghamer P, Hargrave B, Peer D, Hawkins CM (1986) Partitioning of production and respiration among size groups of organisms in an intertidal benthic community. Mar Ecol Prog Ser 31:131-142

Steiger JH (1980) Tests for comparing elements of a correlation matrix. Psychol Bull 87:245-251

Stone M (1974) Cross-validatory choice and assessment of statistical predictions (with discussion). J R Stat Soc B 36: 111-147

Summerson HC, Peterson CH (1984) Role of predation in organizing benthic communities of a temperate-zone seagrass bed. Mar Ecol Prog Ser 15:63-78

Tumbiolo ML, Downing JA (1994) An empirical model for the prediction of secondary production in marine benthic invertebrate populations. Mar Ecol Prog Ser 114:165-174

Underwood AJ (1997) Experiments in ecology: their logical design and interpretation using analysis of variance. Cambridge University Press, Cambridge

Urban HJ, Campos B (1994) Population dynamics of the bivalves Gari solida, Semele solida and Protothaca thaca from a small bay in Chile at $36^{\circ} \mathrm{S}$. Mar Ecol Prog Ser 115: 93-102

Vetter EW (1995) Detritus-based patches of high secondary production in the nearshore benthos. Mar Ecol Prog Ser 120:251-262

Vetter EW (1998) Population dynamics of a dense assemblage of marine detritivores. J Exp Mar Biol Ecol 226:131-161

Warwick RM (1980) Population dynamics and secondary production of benthos. In: Tenore KR, Coull BC (eds) Marine benthic dynamics. Univ South Carolina Press, Columbia, $\mathrm{SC}, \mathrm{p} 1-24$

Waters TF (1977) Secondary production in inland waters. Adv Ecol Res 10:91-164

Waters TF (1979) Influence of benthos life history upon the estimation of secondary production. J Fish Res Board Can 36:1425-1430

Willows RI (1987) Population and individual energetics of Ligia oceanica (L.) (Crustacea: Isopoda) in the rocky supralittoral. J Exp Mar Biol Ecol 105:253-274

Woodin SA (1978) Refuges, disturbance, and community structure: a marine soft-bottom example. Ecology 59: 274-284

Zaïka VE (1970) Rapports entre la productivité des mollusques aquatiques et la durée de leur vie. Cah Biol Mar 11:99-108

Zar JH (1999) Biostatistical analysis. Prentice-Hall, Englewood Cliffs, NJ

Submitted: August 31, 2004; Accepted: May 10, 2005

Proofs received from author(s): June 21, 2005 